
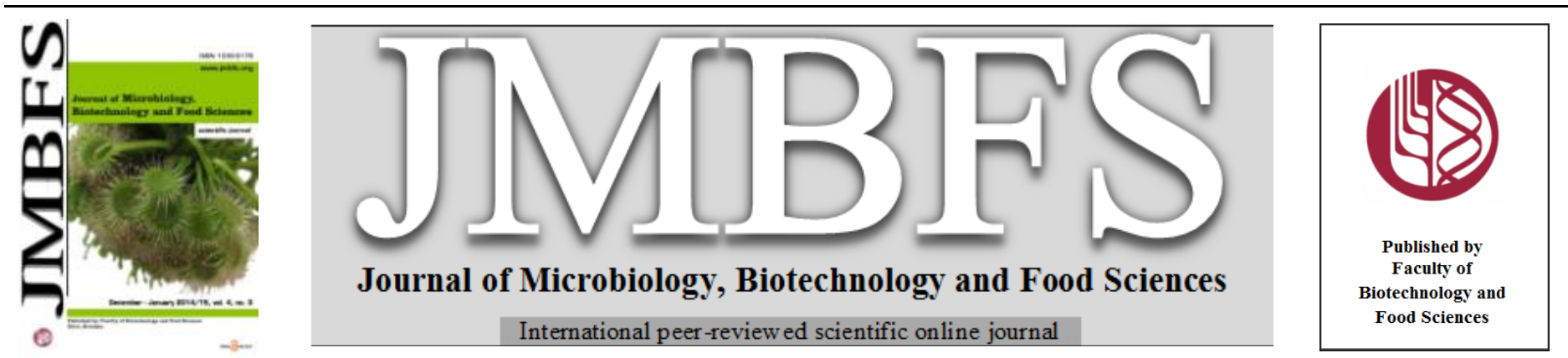

\title{
THE IMMUNOLOGICAL STRUCTURE OF POPULATION OF KARAKUL LAMBS BUCCINATED AGAINST CONDITIONALLY AND ACUTE PATHOGENOUS BACTERIA
}

\author{
Rachmatullo Ruzikulov
}

Address(es): Samarkand Agricultural Institute, Veterinaru, Mirzo Uluqbek, 77, 140103, Samarkand, Uzbekistan, +998662343320.

*Corresponding author: samai akmal@yahoo.com

doi: 10.15414/jmbfs.2014-15.4.3.209-212

\section{ARTICLE INFO}

Received 8. 9. 2014

Revised 7. 10. 2014

Accepted 16. 10. 2014

Published 1. 12. 2014

Regular article

OPEN $\partial_{\text {ACCESS }}$

\begin{abstract}
Antibodies, developing in animal and human organisms against antigens of external and internal origin are not limited with opsonization functions, lying on the base of formation of humoral immunity. Being the product of somatic mutations of plasmatic cells, according to clonal selection theory of immunity, they themselves are also alien proteins for organisms. Thus, they themselves also begin to display antigen pressure on the immune competent system. So, they will start themselves the elaboration of antibodies against them, which are called anti-idiotypic ones. Anti-idiotypic antibodies, imitating the corresponding bacterial and virus antigens are able to initiate the immune response of animal organism against them, which play great immune modulating role.

The immunological structure of populations of Karakul sheep lambs vaccinated against E. coli bacteria, salmonellosis and anthrax antigen from the age of 2-3 days till 2-3 weeks was studied. Experiments were carried out in the 1-2, 3-4, 5-6, 7-8, 9-10 and 11-12 weeks old Karakul lambs. Experimental lambs during appraisal were vaccinated once by associated hydroxide aluminum form vaccine against paratyphoid and coli bacteriosis of calves, pigs and lambs. In another experiment, the lambs were immunized by rare naturally occurring bacterial antigen. As such an immunogenic was selected sterile soluble anthrax antigen. Developed and tested in the application of Ascoli reaction the role of anti-idiotype antibodies in the formation of natural immunity against opportunistic pathogens identified the nature of normal antibodies was studied. The nature of wavelike character of the immune reaction of an organism of newborn animals of vaccination was revealed. Also the immunomodulation role of anti-idiotypic antibodies was determined.
\end{abstract}

Keywords: Conditionally-pathogenic microorganisms, immunity, bacterial antigens, colostral antibodies, anti-idiotypic antibodies

\section{INTRODUCTION}

At present all over the world there is marked the aggravation of the problem, connected with conditionally-pathogenic microorganisms of people and animals. First of all it is connected with difficult measurement of specific prophylaxis conducted against obligatory pathogenic microorganisms. Detection is complicated as conditionally-pathogenic microorganisms are natural inhabitants of animal organisms (Frolov et al., 1999).

Thus, the significance of natural immune status of animals against conditionallypathogenic microorganisms becomes prior. On one hand, type, breed, age, constitution and other properties of animals are important, on the other handmicrobiological parameters of their living environment are also associated (Jeleznikova, 2006). The numerous researches confirm that problems of conditionally-pathogenic microorganisms are displayed more acutely with reform and immuno-deficient individuals of all types of agricultural animals (Dumova 2006; Federov 2006).

Under conditions of industrial animal breeding, epizootic acute infections loose their laddering significance and they are replaced by diseases, stipulated by conditionally-pathogenic microflora (Lvov, 1997). Besides, up to present time at planning and currying out treatment-prophylaxis measures, especially vaccine prophylaxis, it is not enough to take into consideration the individual immune status of microorganism (Petrov, 1992). Moreover the appeared scientific works are waiting for their generalization and comprehension and for a while they have not become the integrated element in the system of struggle against infections.

\section{MATERIAL AND METHODS}

The researches were carried out with $1-2,3-4,5-6,7-8,9-10$ and 11-12 weeks old Karakul sheep lambs in the stud from "Nurata" of Nurata district of Navoi district of the Republic of Uzbekistan.

The determination of post-vaccinal antibodies against all studied bacterial antigens was carried out in the reaction of agglutination. For carrying out the reaction of agglutination as antigen there was used the living daily cultures of pathogenic E. coli bacteria, Salmonella, singled out in the laboratory of microbiology of Uzbek Veterinary Scientific-Research Institute. Normal hem agglutinins were determined in relation to washed up poultry erythrocytes with physiological solution. Anti-antrax precipitins in the reaction of scaly and according to immuno-diffusion of anti-enterococcus precipitins were used. Besides, there were calculated the percent correlation of lambs, which have more or less average - arithmetic meaning of titles of agglutinins to the total number of lamps in group, both in relation to every studied antigen separately, and in relation to their combination.

\section{RESULTS AND DISCUSSION}

The immunological structure of karakul sheep lambs population vaccinated against $E$. coli and Salmonella from the age of 2-3 days

The experimental lambs during bonitiration were vaccinated one time with associated hydrooxidealuminium formal vaccine against $E$. coli and paratyphus of calves, piglets and lambs. As it is shown, the results of experiments, adduced in the Table 1 are as follows: antibodies are registered in lambs of the age of 1-2 weeks, vaccinated against $E$. coli and paratypus at the age of 2-3 days, both against vaccinating antigens, and against erythrocytes of poultry. 
Table 1 The dynamics of specific and normal agglutinins in the serum of blood of Karakul-sheep lambs, vaccinated from the age of 2-3 days against E. coli and Salmonella $(\mathrm{X} \pm \mathrm{s})$

\begin{tabular}{l|lccc}
\hline & \multirow{3}{*}{ № } & Spectrum & The age (in weeks) and number of lambs & \\
\cline { 2 - 5 } & of agglutinins & $1-2(\mathrm{n}=120)$ & $3-4(\mathrm{n}=120)$ & $5-6(\mathrm{n}=115)$ \\
1 & E. coli agglutinin & $1: 125 \pm 1.02$ & $1: 140 \pm 1.08$ & $1: 50 \pm 0.65$ \\
2 & Salmonella agglutinin & $1: 80 \pm 0.81$ & $1: 85 \pm 0.84$ & $1: 140 \pm 1.41$ \\
\hline $\mathbf{3}$ & Haemo agglutinin & $1: 16 \pm 0.36$ & $1: 12 \pm 0.31$ & $1: 115 \pm 1.28$ \\
\hline
\end{tabular}

As it is seen from the table, the anti-Salmonella agglutinins and haemoaglutinines of lambs of the age of 1-2 and 3-4 weeks fluctuated approximately on the same range, and those of anti-coli bacteria agglutinins considerably raised. At the 5-6 weeks of postnatal life the agglutinins against vaccinating antigens sharply reduced up to negative meanings in mixing the serum with water for the reaction of agglutination $-1: 50$ and higher. At the 7-8 weeks of postnatal life the specific agglutinins vaccinating antigens raised again up to previous meanings and even higher, though the revaccination was not carried out.

The analysis of immunological structure of populations of Karakul sheep lambs, vaccinated at the age of 2-3 weeks against Coli bacteria and paratyphus, carried autoscoring to the percent correlation of the number of lambs, having the agglutinins more or less of average arithmetic means, made in possible to clarify it.

It was revealed that two waves of the immune reaction of lambs of the same experimental group have different nature. If it is taken into consideration that the immune status and immunity in general may be of 2 types: passive and active, it is possible to confirm, that the first wave of the growth of the title of agglutinins is passive, that is non post-vaccine, and the second wave active - post-vaccine or another origin (Milgrom and Swierczynska, 1986).

Actually, the percent correlation of the number of high and low immune status of lambs (Heath and Holcman, 1997) in conformity with coli bacterial, Salmonella and erythrocyte antigens at the age of 1-2 and 3-4 weeks as a whole had the similar picture (Table 2).

Table 2 The dynamics of correlation of quantity of high and law reacting lambs, vaccinated from the age of 2-3 days against $E$. coli bacteria and Salmonella (in \%)

\begin{tabular}{l|lccc}
\hline \multirow{2}{*}{ № } & & \multicolumn{4}{|c}{ The age (in weeks) and the number of lambs } \\
\cline { 2 - 5 } & The spectrum & $1-2(\mathrm{n}=120)$ & $3-4(\mathrm{n}=120)$ & $5-6(\mathrm{n}=115)$ \\
1. & of agglutinins & $15.83 / 21.66$ & $29.91 / 24.79$ & $27.93 / 47.83$ \\
2. & E. coli agglutinin & $16.66 / 40.83$ & $15.20 / 28.07$ & $30.41 / 43.27$ \\
\hline 3. & Salmonella agglutinin & $29.16 / 19.17$ & $32.48 / 42.73$ & $14.78 / 20.87$ \\
\hline
\end{tabular}

As is seen from the Table 2, the correlation of high immune and low immune lambs in general is conducted during the first month of postnatal life, when the colostrial immunity is revealed following in favor of high coreagating for $E$. col bacteria agglutinins, in favor of high coreagating ones - for Salmonella and variation ones - for hem agglutinins (Jegerlehner et al., 2013).

At 5-6 weeks, when there was observed the immune falling off in all 3 agglutinins, distinct tendency was not revealed. It is possible to permit that this testifies about transitive character of this period, when the organism develop from the colostrum immunity to creation of active immunity.

The results of the experiment persuade that 2 peaks of the raising and falling of the lever of immune bodies in the lamb blood serum vaccinated against $E$. coli bacteria and paratyphus at the age of 2-3 days differ, but are closely connected. As the evident confirmation of this fact in both cases is prevailed high immune $E$. coli bacteria agglutinins of lambs vaccinated against $E$. coli bacteria and paratyphus. From the age of 2-3 weeks the absence of parabolic character of immune reaction to the vaccination, which describes ineffectiveness at this age is evident.

A deeper analysis of immunological structure of the population of Karakul sheep lambs vaccination from the age of 2-3 days was carried out with the aim of establishing the percent correlation of the number of lambs, having the agglutinin of more or less meanings simultaneously against 2-3 studied antigens (Table 3 ).

Table 3 The dynamics of parent correlation of quantity of high and law reacting lambs, vaccinated from the age of 2-3 weeks against E. coli bacteria and Salmonella (in\%)

\begin{tabular}{l|lcccc}
\hline \multirow{2}{*}{ № } & The spectrum & of agglutinins & \multicolumn{4}{c}{ The age (in weeks) and number of lambs } \\
\cline { 2 - 6 } & & $1-2$ & $3-4$ & $5-6$ & $7-8$ \\
& & $(\mathrm{n}=120)$ & $(\mathrm{n}=120)$ & $(\mathrm{n}=115)$ & $(\mathrm{n}=70)$ \\
2 & E. coli and Salmonella agglutinins & $6.67 / 9.17$ & $5.13 / 24.79$ & - & $13.89 / 15.28$ \\
3 & E. coli haemo-agglutinins & $12.50 / 11.67$ & $10.20 / 25.64$ & $7.83 / 11.30$ & $22.22 / 8.33$ \\
$\mathbf{4}$ & Salmonella haemo-agglutinin & $3.33 / 19.17$ & $3.42 / 19.66$ & - & $9.72 / 9.72$ \\
\hline
\end{tabular}

The results of such analysis, first of all, show that the quality of lambs, having high title of agglutinins simultaneously against 2 antigens is 3-4 times, and against 3 antigens is 5-6 times lower, than in lambs having high title of agglutinins against 1 antigen.

The most remarkable thing is the evident connection of $E$. coli bacteria agglutinins and hem agglutinins, which is expressed in prevalence of the quantity of lambs, having agglutinins higher average arithmetic meanings in their connectional type as during experiments, conducted on the vaccinated lambs at the age of 2-3 days, there the paradoxical result in the form of post vaccine falling and separate raising of titles of specific agglutinins was found. The necessity of carrying out the experiments with other terms of vaccination appears.
For this purpose the immunological structure of populations of Karakul sheep lambs vaccinated at the age of 2-3 weeks was studied.

The immunological structure of populations of Karakul sheep lambs, vaccinated against $E$. coli bacteria and Salmonella from the age of 2-3 weeks

An experiment was carried out on 50 lambs for this purpose. Animals were also vaccinated against $E$. coli bacteria and paratyphus, but the vaccination was carried out from the age of 2-3 weeks giving absolutely different result (Table 4).

Table 4 The dynamics of specific and normal agglutinins in the serum of blood of Karakul-sheep lambs, vaccinated from the age of 2-3 weeks against E. coli bacteria and Salmonella $(\mathrm{X} \pm \mathrm{s})$

\begin{tabular}{l|lccc}
\hline \multirow{2}{*}{ No } & The spectrum & \multicolumn{3}{c}{ The age (in weeks) and the number of lambs } \\
\cline { 2 - 5 } & of agglutinins & $3-4(\mathrm{n}=50)$ & $5-6(\mathrm{n}=40)$ & $10-11(\mathrm{n}=30)$ \\
1 & E. coli agglutinin & $1: 125 \pm 1.58$ & $1: 565 \pm 3.75$ & $1: 215 \pm 2.67$ \\
2 & Salmonella agglutinin & $1: 70 \pm 1.18$ & $1: 125 \pm 1.76$ & $1: 175 \pm 2.41$ \\
\hline $\mathbf{3}$ & Haemo agglutinin & $1: 16 \pm 0.56$ & $1: 80 \pm 1.41$ & $1: 150 \pm 2.23$ \\
\hline
\end{tabular}


The result of this experiment shows that the immune reaction of the vaccination was more expressive and has brightly expressive parabolic character. In reality, in this case the growth of agglutinins against Salmonella antigens was reserved but more protracted. In even more contrast there was revealed the prevalence of the number of lambs with high average arithmetic titles of E. coli agglutinins and the quantity of lambs with law overage arithmetic titles of haemoagglutinines (Table 5).

As for the percent correlation of the quantity of lambs with higher and lower average arithmetic titles of Salmonella agglutinin, it was special in this experiment, and was expressed in that the prevalence of high reacting ones was only during the highest raise of the immune and fast passing, at the rest time of immune response on vaccination in titles of agglutinins against Salmonella antigens there prevailed the number of law reacting lambs.

Besides, the law level of the quantity of lambs with higher and lower average arithmetic titles of Salmonella agglutinins, predetermined it and regarding E. coli, Salmonella, besides $E$. coli haemoagglutinines. The important result of this experiment is that as a whole the percent correlation of the number of lambs, which have higher and lower average arithmetic meanings of titles of $E$. col bacteria, Salmonella and haemoagglutinines. According to their character they strongly reflected the second one that is the active wave of lambs with the only difference, that the level of antibodies of them was 2-3 times higher.

Table 5 The immunological structure of Karakul sheep lambs, vaccinated against E. coli bacteria and paratyphus age of 2-3 weeks expressed in correlation of the percent of high and law reaction

\begin{tabular}{|c|c|c|c|c|}
\hline \multirow{2}{*}{ № } & \multirow{2}{*}{ Indexes } & \multicolumn{3}{|c|}{ The age (in weeks) and the number of lambs } \\
\hline & & $3-4(n=50)$ & $5-6(n=40)$ & $10-11(n=30)$ \\
\hline 1 & The quantity of lambs with $E$. coli agglutinin & $34.70 / 14.30$ & $45.65 / 24.0$ & $55.90 / 29.47$ \\
\hline 2 & The quantity of lambs with Salmonella agglutinin & $2.04 / 53.06$ & $32.61 / 17.40$ & $23.53 / 53.0$ \\
\hline 3 & The quantity of lambs with haemo agglutinin & $16.30 / 36.70$ & $17.40 / 24.0$ & $17.94 / 53.0$ \\
\hline 4 & $\begin{array}{l}\text { The quantity of lambs with E. coli and Salmonella } \\
\text { agglutinin }\end{array}$ & $0.0 / 4.08$ & $26.09 / 6.52$ & $20.60 / 40.0$ \\
\hline 5 & $\begin{array}{l}\text { The quantity of lambs with } E \text {. coli } \\
\text { haemoagglutinin }\end{array}$ & $8.16 / 8.16$ & $6.53 / 6.52$ & $14.82 / 29.64$ \\
\hline 6 & $\begin{array}{l}\text { The quantity of lambs with Salmonella } \\
\text { haemoagglutinin }\end{array}$ & $0.0 / 18.36$ & $4.09 / 2.05$ & $8.82 / 44.12$ \\
\hline 7 & $\begin{array}{l}\text { The quantity of lambs with E. coli and Salmonella } \\
\text { haemoagglutinin }\end{array}$ & $0.0 / 2.04$ & $4.09 / 2.05$ & $8.82 / 20.60$ \\
\hline
\end{tabular}

The results of experiments of immunological structure of Karakul sheep lambs, vaccinated against $E$. coli bacteria and paratyphus form the age of 2-3 days and 2-3 days revealed earlier unnoticed aspects of setting post-vaccinal immunity of new born lambs, which touched the conceptual sides of immunology (FassiFehri et al., 1984). In this light there appeared the necessity of deeper checking up the arising of a new concept on the setting of new concept on formation of immune status against microbial surrounding of new-born lambs, which as it is known, are conditionally-pathogens microorganisms (Nowak and Poindron, 2006).

The fundamental of this problem has become the revealing the nature of wavelike character of immune reaction of organism of newborn lambs to the vaccination. The wavelike immune reaction of newborn lambs, vaccinated from the age of 2 3 weeks, which allows to make supposition that, beginning from the second half of the month of postnatal life, there are turned on the mechanism of active supposition synchronically with this unknown factor on the 2-3 week of postnatal life as the lambs were immunized with rarely met in nature bacterial antigen as such an immunogenic there was chosen the sterile soluble anthrax.

\section{The immunological structure of the population of Karakul sheep lambs, vaccinated from the age of $2-3$ weeks with anthrax antigen}

The experiments were conducted on 50 newborn lambs. The lambs were vaccinated with sterile soluble anthrax antigens in ampoules, used for positing the reaction of Ascoli. The antigen was injected once hypodermically into hip. The doze of antigen is $1 \mathrm{ml}$.

As the results of the experiment show (Table 6) in this case are also produced specific and normal antibodies against $E$. coli bacteria, enterococcus and horological erythrocytes antigens that are agglutinins and precipitins in wavelike form. The data of Table 6 show that the title of $E$. coli agglutinins of lambs falls by $5-6$ weeks in comparison with the previous age and during all the following period of researches there was a sharp raising.

Table 6 The dynamics of the level of specific and normal antibodies in the serum of Karakul - sheep lambs immunizated from the age of $2-3$ weeks with saleable anthrax antigen $(\mathrm{X} \pm \mathrm{s})$

\begin{tabular}{l|lccccc}
\hline \multirow{2}{*}{ № } & The spectrum & The age (in weeks) and number of lambs & & \\
\cline { 2 - 6 } & of agglutinins & $3-4$ & $5-6$ & $7-8$ & $9-10$ & $11-12$ \\
$(\mathrm{n}=50)$ & $(\mathrm{n}=50)$ & $1: 50)$ & $1: 745 \pm 3.86$ \\
1 & & $(\mathrm{n}=50)$ & $1: 60 \pm 1.09$ & $1: 350 \pm 2.64$ & $1: 2425 \pm 6.96$ \\
2 & E. coli agglutinin & $1: 185 \pm 1.92$ & $1.25 \pm 0.15$ & $1.13 \pm 0.15$ & $1.26 \pm 0.15$ & $1: 10 \pm 0.44$ \\
3 & Enterococcus precipitin & $0.88 \pm 0.13$ & $1: 8 \pm 0.40$ & $1: 8 \pm 0.40$ & $1: 5 \pm 0.31$ \\
\hline $\mathbf{4}$ & Anthrax precipitin & $1: 10 \pm 0.44$ & $1: 30 \pm 0.77$ & $1: 14 \pm 0.52$ & $1: 40 \pm 0.89$ \\
\hline
\end{tabular}

The analogous fallings and raisings were characteristic both for the font of immune diffusion of anti-enterococcus precipitins. However the changes of antibodies in these cases by the time fell behind from the previous time, so the falling was registered on 7-8 weeks, then followed the statistically authentic raising. These results essentially confirmed earlier obtained data of the previous series of experiments (Dushanov et al., 1987).

The results of experiments on the study of immunological structure of populations vaccinated against $E$. coli bacteria, paratyphus and anthrax of lambs, allowed us to reveal a number new immunological phenomenon. The main of them is that from the very beginning of postnatal life of animals there was formed the strong immune status against infection origin of microbiological surroundings, in which formation the colostrum antibodies served as initial material and determining base. During the first month of postnatal life the cloistral antibodies form the immune status against microbial surrounding in the form of passive immunity.

However in the future, beginning from the age of 2-3 weeks begins elaboration of anti-idiotypical antibodies against colostrum antibodies, which accumulate and modify and begin to render the antigen influence, imitating the properties of corresponding bacterial and virus antigens and determine the formation of active immune status against inflectional origin. The contacting or uncontracting of organism of newborn lamb with this or that antigen of microbiological surrounding was studied (Blache and Bickell, 2011).

The results are new for the immune reaction on the sterile soluble anthrax antigen. After registration of quick response to the infection of anthrax antigen in a week after vaccination of lambs of the age of 3-4 weeks, there followed the same falling of anti-anthrax precipitins, which was more protracted and was observed at 5-6 and 7-8 weeks old lambs. It was unexpected that in 1-2 months after vaccination there was registered the second raising of title of anti-anthrax precipitins in the serum of blood of experimental lambs, which can not be considered as an immune response to the injected antigen.

However, it should not be considered and is not connected with immunization of anthrax antigen (Chauhan et al., 2014). It is still the most probable assumption, that the second wave of the raise of the title of anti-anthrax precipitines is the immune response to anti-idiotypical antibodies, imitating the immune properties of anthrax bacterial antigens. Actually, the same thing is testified disconnected character falling of the title of anti-anthrax precipitins at the 11-12 weeks of postnatal life (Kamal et al., 2011).

Disconnected character of the wavelike immune reaction of organism of newborn lambs anthrax antigen on comparison with others studied immune responses is explained that nature bacterial antigens and anti-colostral anti-iditypical antibodies, imitating bacterial antigens in organism are accumulated and reduced 
gradually. It cannot be said in the respect of accumulation of antibodies against single moment injected anti-anthrax antigens, produced as a result of corresponding anti-iditypical antibodies. Namely the latter causes the second wave of raise of the title of reaction Ascoli, imitating anthrax antigens (Hahn et al., 2006).

One more important result of this experiment is the determination of the nature of wavelike immune reaction on conditionally-pathogen microorganisms, which is not the result of vaccination, but natural phenomenon. Synchrony of waves of immune reaction to anti-colostral anti-iditypical antibodies, presenting conditionally-pathogens microorganisms and injection of anthrax antigens to lambs of the age of 2-3 weeks revealed the new nature of formation of active immunity both in natural conditions and at vaccination.

\section{CONCLUSION}

It can be concluded that in lambs there is formed first passive and then active immunity against studied conditionally-pathogen of non-infection origin. The dynamics of formation of immune status has a wavelike character. The first maximum of this immune status was detected during 1-2 weeks of postnatal life. The second maximum of immune status was found during 5-8 weeks of postnatal life. The participation of antigen pressure of microbial surrounding in the formation of immune status takes place synchronically with anti-idiotypical antibodies, but the first wave of title of antibodies has mainly anti-colostral antiidiotypical nature.

The anti-colostral anti-idiotypical and anti-microbial immune reactions of organism of newborn lambs are on the base of formation of natural immune status against conditionally-pathogens and serve as the measurement of withstanding of pathogenity of microorganisms. The results show that antiidiotypic antibodies fulfill the immunomodeling role regarding the microbial surrounding of animals.

\section{REFERENCES}

BLACHE, D., BICKELL, S.L. 2011. External and internal modulators of sheep reproduction. Reproductive Biology, 11(S3), 61-77.

CHAUHAN, R., WADHWA, G., SHARMA, S.K., JAIN, C.K. 2014. Patent prospects toward therapeutics and diagnostics of anthrax. Recent Pathology and Anti Infective Drug Discovery, 9(1), 52-61. http://dx.doi.org/10.2174/1574891X09666140822112055

DUMOVA, V.V. 2006. Peculiarities of immunodefiencies of cattle. Veterinary, Moscow, 9, 17-18

DUSHANOV, A.D., PETROV, R.V., KHAITOV, R.M. 1987. Genetics of the immune response of Karakul sheep immunized with E. coli and Salmonella vaccines. An analysis of the intensity of the immune response in 2 d-generation and reverse-cross hybrids]. Journal of microbiology, epidemiology and immunobiology, 1, 80-84.

FASSI-FEHRI, M., EL-HARRAK, M., JOHNSON, D., ABBADI, M., ELIDRISSI, A.H. 1984. Experimental study of postvaccinal immunity to sheep-pox. Annales de Recherches Veterinaires, 15(1), 59-64.

FEDEROV, Y.N. 2006. Immunodeficiency of cattle. Veterinary, Moscow, 1, 3-7. FROLOV, A.F., ZARITSKIY, A.M., FELDMAN, M. 1999. Once more about the conditional pathogenousity of microorganisms. Journal of microbiology, epidemiology and immunology Moscow, 5, 96-98.

HAHN, U.K., AICHLER, M., BOEHM, R., BEYER, W. 2006. Comparison of the immunological memory after DNA vaccination and protein vaccination against anthrax in sheep. Vaccine, 24(21), 4595-4597. http://dx.doi.org/10.1016/j.vaccine.2005.08.025

HEATH, D.D., HOLCMAN, B. 1997. Vaccination against echinococcus in perspective. Acta Tropica, 67(1-2), 37-41. http://dx.doi.org/10.1016/s0001706x(97)00054-5

JEGERLEHNER, A., ZABEL, F., LANGER, A., DIETMEIER, K., JENNINGS G.T., SAUDAN, P., BACHMANN, M.F. 2013. Bacterially produced recombinant influenza vaccines based on virus-like particles. PLoS One, 8(11). e78947. http://dx.doi.org/10.1371/journal.pone.0078947

JELEZNIKOVA, G.F. 2006. Infection and immunity: The strategy of both sides. Immunology Moscow, 6, 597-614.

KAMAL, S.M., RASHID, A.K., BAKAR, M.A., AHAD, M.A. 2011. Anthrax an update. Asian Pacific Journal of Tropical Biomedicine, 1(6), 496-501. http://dx.doi.org/10.1016/s2221-1691(11)60109-3

LVOV, D.K. 1997. The problems of unregistered and unpredictable infections. Journal of microbiology, epidemiology and immunology, Moscow, 4, 104-114.

MILGROM, F., SWIERCZYNSKA, Z. 1986. Are cross-reacting natural antibodies multispecific? International Archives of Allergy and Applied Immunology, 80(2), 200-210. http://dx.doi.org/10.1159/000234052

NOWAK, R., POINDRON, P. 2006. From birth to colostrum: early steps leading to lamb survival. Reproduction, Nutrition and Development, 46(4), 431-446. http://dx.doi.org/10.1051/rnd:2006023

PETROV, R.V., KHAYITOV, R.M., ORADOVSKAYA, I.V. 2006. The

immunological monitoring of large groups of population of the country.

Immunology, Moscow, 4, 43-52. 